\title{
天塩川河口二層流の乱流計測 \\ Turbulence Measurement of Two-layer Flow \\ in the Teshio River Estuary
}

西田修三・吉田静男 $\cdots \cdot 大$ 谷守正 $\cdots$

By Shuzo NISHIDA, Shizuo YOSHIDA and Morimasa OHTANI

We have made the field observation of turbulent flow in the tidal portion of Teshio river, using a two-dimensional LDV system of our making. The turbulence energy and Reynolds stress were higher in an upper layer than in a lower layer due to surface wave with the frequency of $0.3 \mathrm{~Hz}$, but there existed the velocity fluctuation of $1 \mathrm{~Hz}$ in the whole depth with about equal intensity. Turbulent intensities of vertical velocity component were proportion to that of horizontal velocity component.

Keywords : field observation, turbulence, estuary, tidal river

1.はじめに

実河川の流況・水質の数値予測には、流れ場の正確な乱 流量の把握が不可欠である。しかしながら、現在まで、実 河川におけるレイノルスス応力ゃ密度フラックスといった乱 流量を測定した例はほとんどなく、流況・水質の数値シミ ユレーションに際しては、室内実験の結果や数少ない野外 調査結果を基に、乱流係数が決定されてきた。これは、数 値解析に十分応え得る乱流量の測定が可能な計測器が存在 しなかったことにも起因している。そこで、筆者らは数值 シミュレーションに必要な実河川の合理的・実用的な乱流 係数の決定を最終目的に、試作の 2 次元レーザー流速計を 用いた実河川の乱流計測システムの開発と現地調査を行っ

* 正会員 工博 八戸工業大学助教授 工学部土木工学科

( テ031 青森県八戸市大字妙字大開8 8-1)

** 正会員 工博 北海道大学助教授 工学部数物系共通講座

(厂060 北海道札帽市北区北 13 条西 8丁目)

*** 正会員 工博 北海道大学助手 工学部数物系共通講座

( 个060 北海道札幌市北区北 13 条西 8丁目)

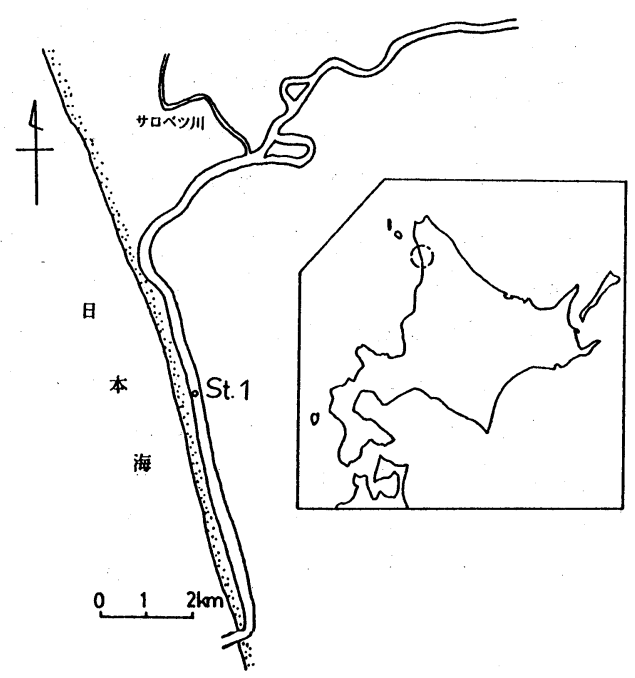

図 - 1 観測地点 


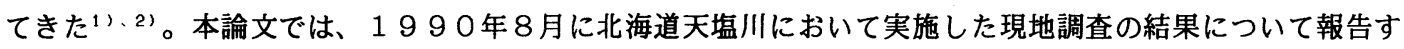
る。

2. 測 定 方 法

天塩川（図-1）は、日本海に河口を有し、北海道では石狩川に次ぐ流路長をもつ一級河川である。河口 から上流 $7 \mathrm{k} \mathrm{m}$ までは水深 $5 \mathrm{~m}$ 、河幅 $200 \sim 300 \mathrm{~m}$ のほぼ一様な直線流路となっており、密度構造は密 度の急変する内部境界面を有する典型的な弱混合河川である。調査は、1990年8月 3 日〜 4 日まで河口 より上流 5. $5 \mathrm{~km}$ の河口大橋において実施した。観測地点（S t. 1 ）の河幅は $270 \mathrm{~m}$ 、水深は前年ま でのしゅんせつ工事により両岸を除く約 $200 \mathrm{~m}$ にわたり $5 \mathrm{~m}$ の一様水深であった。主たる調查項目は以下 のとおりである。

1 ) 試作 2 次元L D Vによる乱流計測

2 ) 界面追尾計（自作）による密度境界面の変動計測

3 ) 電気伝導度計による電導度鉛直分布計測

4) 压力式水位計による水位計測

5 ）ＣＭ２型流速計、E S T 3 型水質計を用いた横断 3 地点における流速、塩分の鉛直分布測定

1) 〜 3 ) の各計器の設置状況を図一 2 に示す。

試作の 2 次元 L D Vプローブは、水平方向と鉛直方向の 2 成分流速を検出できるようになっている。 L D Vはその原理上、異なる周波数のビームを使用しない限り流向の判別はできず、試作のL D V システムにお いても、このままでは流向が反転するV、W成分の測定はできない。しかし、主流U（=Um+u）に対し4 $5 \circ$ 傾いた 2 方向の流速成分を測定するようにプローブを設置し、その出力信号を基にU及びV（またはW） 方向成分を一次変換により算定すれば、 $\mathrm{V}$ (またはW）に関して正負の値を得ることができる ${ }^{3)}$ まこで、 今回の測定ではプローブの 2 測定面を主流に対して 45 。傾けてフレームに固定し橋上よりガイドロープに 沿わせて吊り下げ、プローブの動摇を除去した 2 次元の流 速測定を行った。

界面追尾計は、設定された任意の電導度面をセンサーが 上下に追尾し、その変位量に比例した電圧を出力するもの で、通常の内部波高計とは原理的に異なるものである。漸 変成層流における内部波の観測や表面波の観測にも使用か 可能である。ただし、サーボモーターによる制御のため、 周波数応答性に劣り、約 $5 \mathrm{H} \mathrm{z}$ の応答性である。また、自 作電導度計の変換器の回路はブリッジ回路を用いた市販の ものとほぼ同じであるが、プローブを $5 \mathrm{~mm} \varnothing に$ 小型化し、 より正確な鉛直分布測定が可能なようにした。

L D V による流速測定は、各水深においてサンプリング 周波数 $20 \mathrm{~Hz}$ z 410 0個のデータをデジタルデータレ コーダに収録し、持ち帰ってデータの解析を行った。

\section{3. 測 定 結 果}

困ー3は、サンプリング間隔 1 分で計測された観測期間 の水位変化である。また、図 -4 は時間軸を 5 倍に引き伸 ばしたものである。潮差は約 $20 \mathrm{c} \mathrm{m}$ と小さいが、周期が

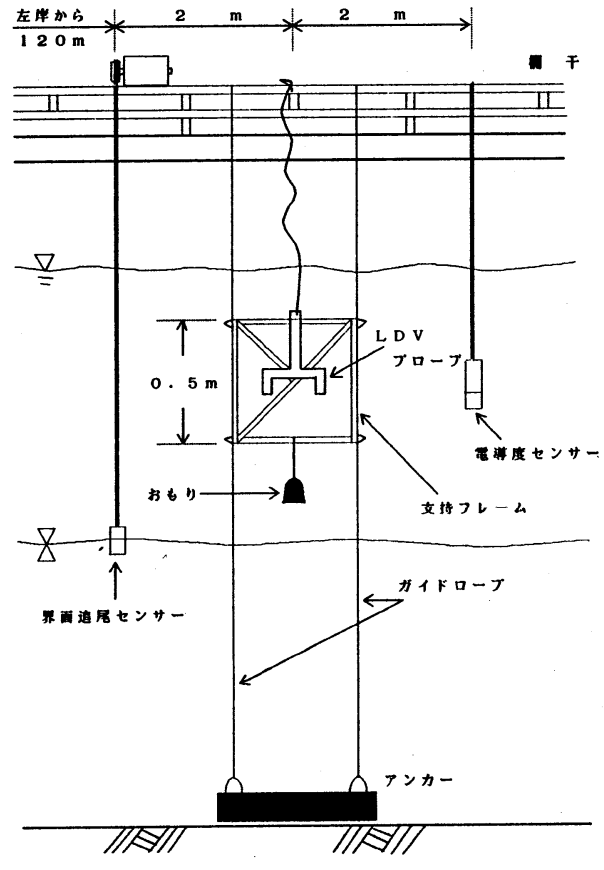

目-2 計器の設置状況 
水位 $(m)$

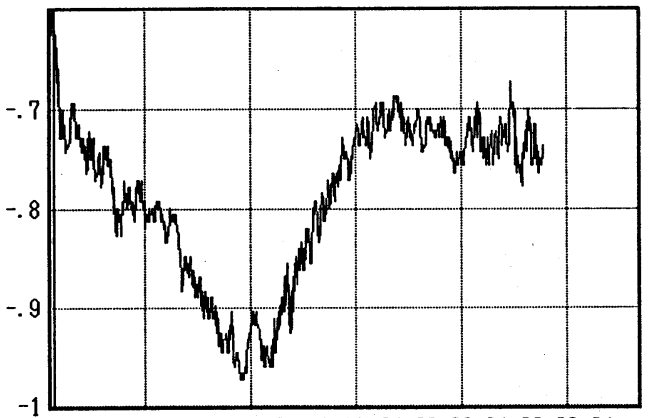

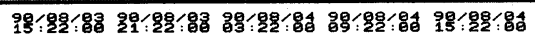
図 -3 水位変化

数分から 1 時間にも及ぶ全振幅 $5 \mathrm{~cm}$ 程度の水位変動 が存在していることがわかる。F F T 法を用いたスペ クトル解析の結果（図-5) にも周期が約 3 分、10 分、20 分の卓越した水位変動が現れており、かなり 強い非定常性が存在し、流れ場に少なからぬ影響を及 ほしていることがうかがえる。

以下、一例として、8月4日8：30〜9:30に 計測されたデータの解析結果について述べる。流速計 測は各水深において 205 秒間行ない、計測終了後、

電導度計を用いた密度の鉊直分布測定、およひ、界面 追尾計による界面変動の計測を行った。

図ー6に、L D Vによって観測された各水深におけ る流速成分（主流方向成分U、鉊直上方成分 V) と流 水位(m)

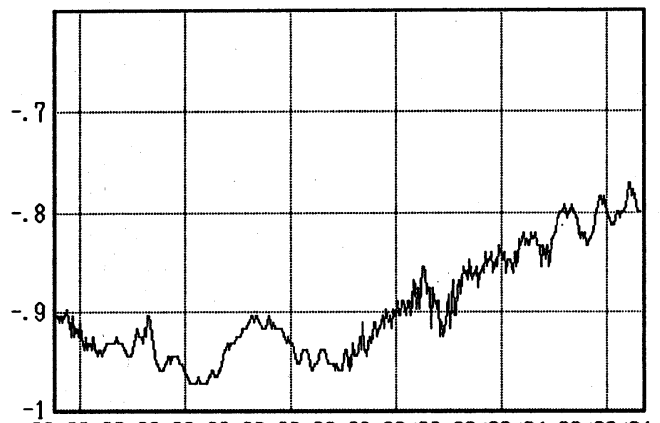

1ำ:영:

図-4 水位変化

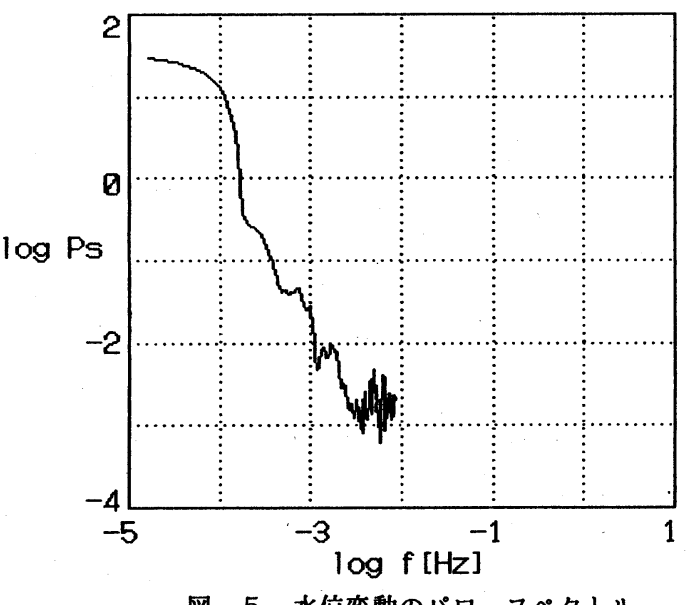

図-5 水位変動のパワースペクトル 速Uのパワースペクトルを示す。図には30秒間の流速データしか示されていないが、解析には 2048 個 （１０２．４秒）のデー夕を用いている。表層で卓越している変動のうち０. $3 \mathrm{H} \mathrm{z}$ の低周波変動は水深が深 くなるにつれ、そのピークは下がり、パワーは $1 / 10$ （水深 $0.1 \mathrm{~m} に$ 比べれば $1 / 100$ ）以下に低下し ている。一方、 $1 \mathrm{H} \mathrm{z}$ のスペクトルピークは界面直上（界面位置は図－9）で若干低下するものの底層まで

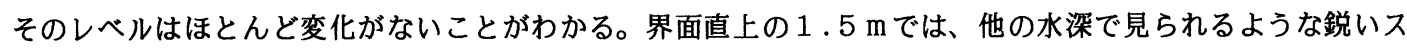
ペクトルピークは存在しないが、幾つかの小さなピークが現れ、高周波側にエネルギーが分散していること がわかる。また、U、Vのパワーを比較してみたところ、低周波成分ではUはV $\mathrm{V}$ 数倍の值を有したが、高 周波成分ではほぼ同程度の值を示していた。

図ー7は、界面追尾計によって得られた界面変動と同時刻に計測された水深 $2.25 \mathrm{~m}$ における流速のパワ 一スペクトルである。両スペクトルとも $0.6 \mathrm{H} \mathrm{z}$ にスペクトルピークが見られ、界面変動と流速変動の良い 対応関係が認められる。しかし、界面変動は約 $3 \mathrm{H} \mathrm{z}$ 付近に鋭いスペクトルピークが見られるが、流速変動 にはそのようなピークは現れておらず、 $3 \mathrm{H} \mathrm{z}$ 程度の高周波の界面変動は流速変動を誘起するほどの振幅は もたず、影響範囲は界面近傍の狭い領域に限られていることがわかる。

図ー8は、流速データを基に計算された平均流速 $(U \mathrm{U})$ ）、乱れ強度 $\left(\sqrt{\overline{\mathrm{u}^{2}}} 、 \sqrt{\overline{\mathrm{v}^{2}}}\right)$ 、乱れエネルギー（ $\left.\mathrm{k}=\left(\overline{\mathrm{u}^{2}}+\overline{\mathrm{v}^{2}}\right) / 2\right)$ 及ひ、レイノルス応力 $(\tau=-\rho \overline{\mathrm{uv}})$ の鉊直分布を描いたものである。前述のよ うに、流れ場はかなりの非定常性を有しているため、平均流速の与え方が乱流量の算定に大きな影響を及ほ す。そこで、本研究では平均流速として、データ（2048個）の単純時間平均值と図-6を参考に $1.2 \mathrm{H}$ 


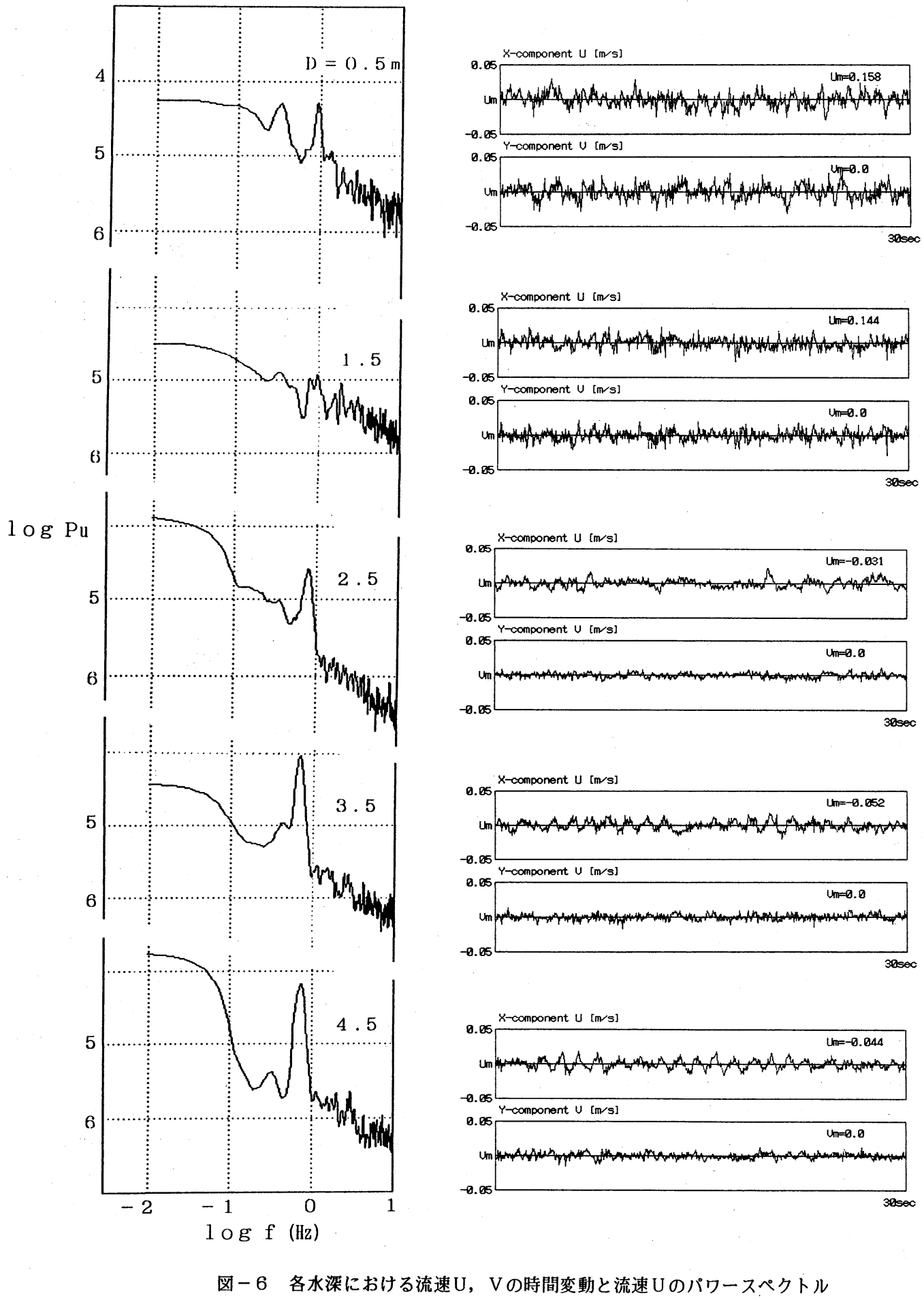


$\mathrm{z}$ の数値 L P F による移動平均の 2 種類を採用し、乱流量の算定を行った。図中、実線が単純時間平均、破 線が移動平均を用いた結果である。すべての乱流量は、表面波の影響で表層において極めて大きな値をもち、 水深の増加とともに急激に減少し、下層内においては若干の減少傾向は見られるものの、ほぼ一定の値を示 している。単純時間平均と移動平均の 2 つの結果を比較してみると、すべての乱流量に関し表層部でフィル ター処理による急激な乱流量の低下がみられる。しかし、下層部ではUの乱れ強度はフィルター処理により、 その值は半減しているものの、Vの乱れ強度およびレイノルズ応力に関しては、その隇少はほとんど認めら れない。これらの結果と前述の図ー6の結果とを総合すると次のことが言える。 $0.3 \mathrm{H} \mathrm{z}$ の卓越した流速変 動は表面波モードの波に起因した乱れと考えられ、表層部でのみ流速変動を誘起し、その乱れは水深方向に
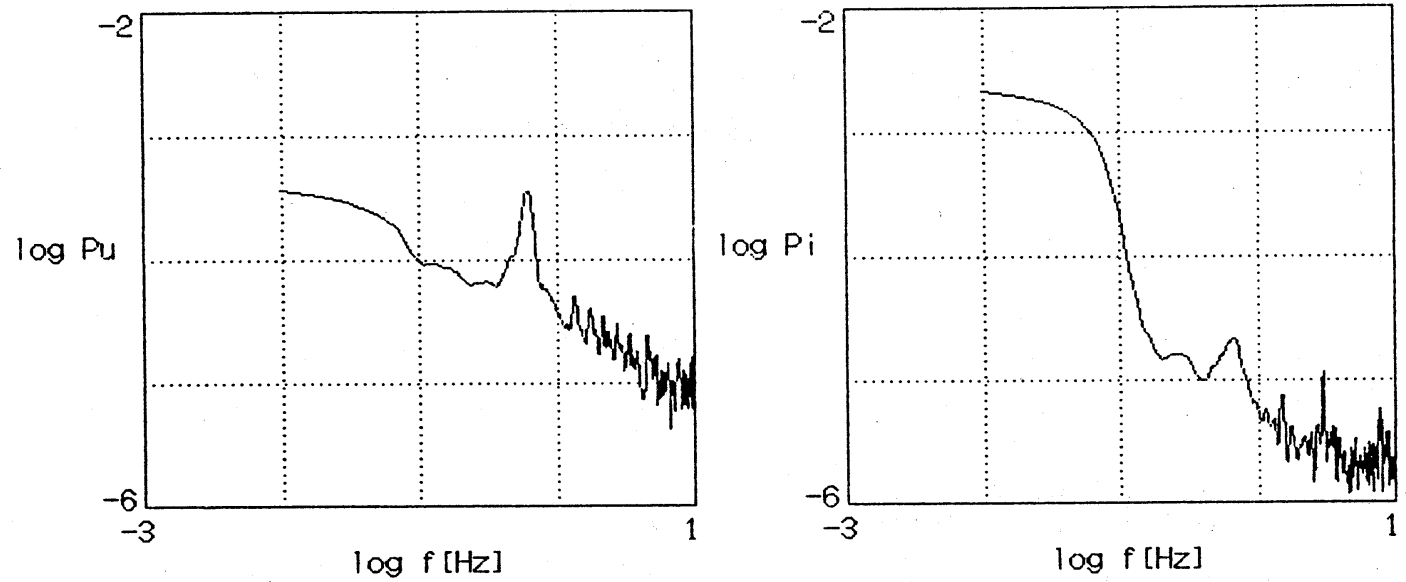

図ー7 流速Uと界面変動のパワースペクトル（水深 $2.25 \mathrm{~m}$ )
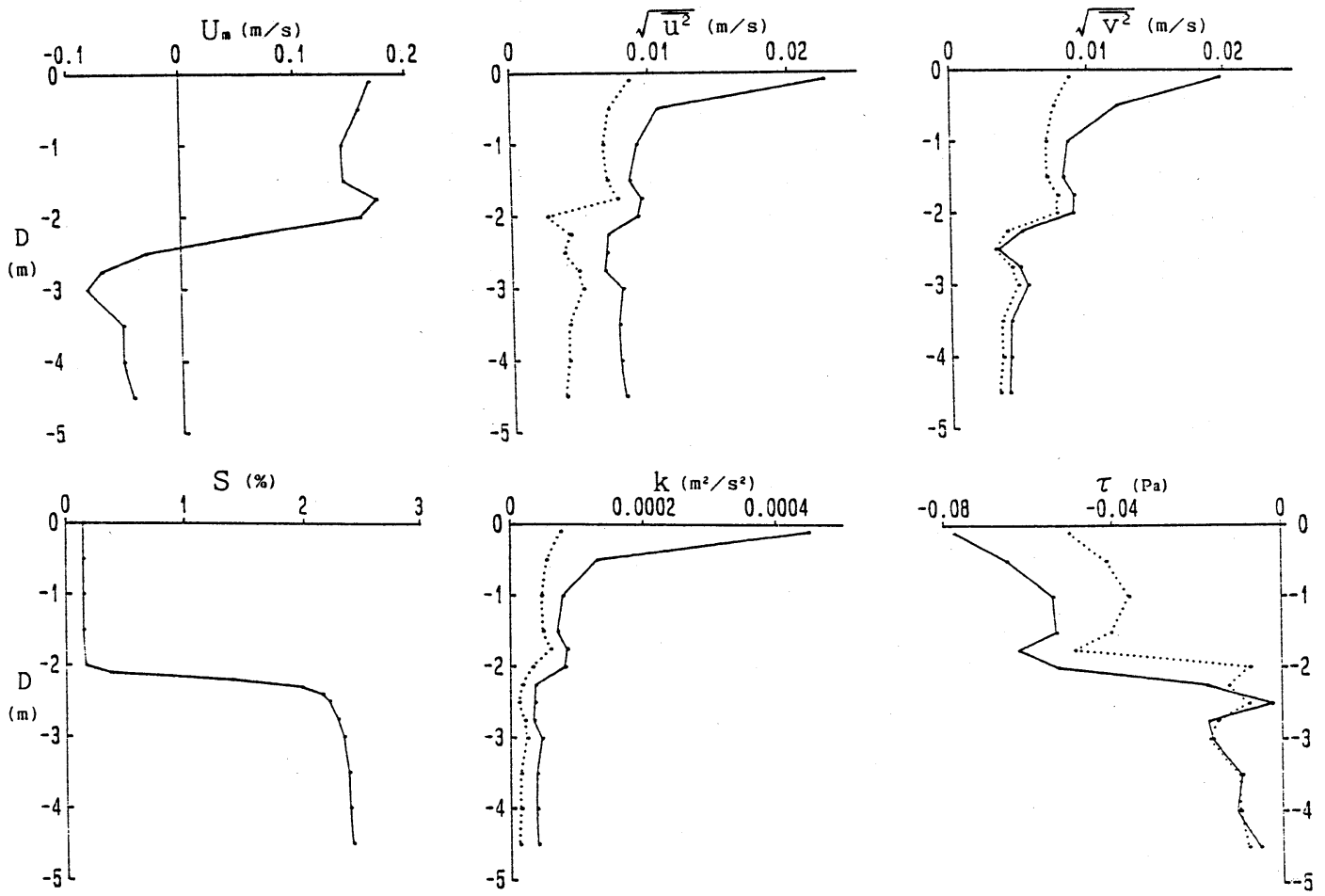

図-8 平均流速 (Um)、乱れ強度 $\left(\sqrt{\overline{\mathrm{u}}^{2}} 、 \sqrt{\overline{\mathrm{v}}^{2}}\right) 、$ 乱れエネルギー $(\mathrm{k})$ 、 レイノルス応力 $(\tau)$ の鉛直分布 
指数関数的に減少する。一方、 $1 \mathrm{H} \mathrm{z}$ の卓越し た流速変動は全層に及んでおり、かつ、その変 動の主方向は鉛直方向ではなく主流方向である と言える。

$\mathrm{U}$ と Vの乱れ強度分布はともに密度境界面付 近とその上下で僅かに極大、極小值を有してお り、その分布形状は極めて良い相似性を示して いる。図ー9は、乱れ強度 (単純時間平均) の 関係を他の計測データとともにプロットしたも のである。乱れ強度が大きい場合にはかなりの

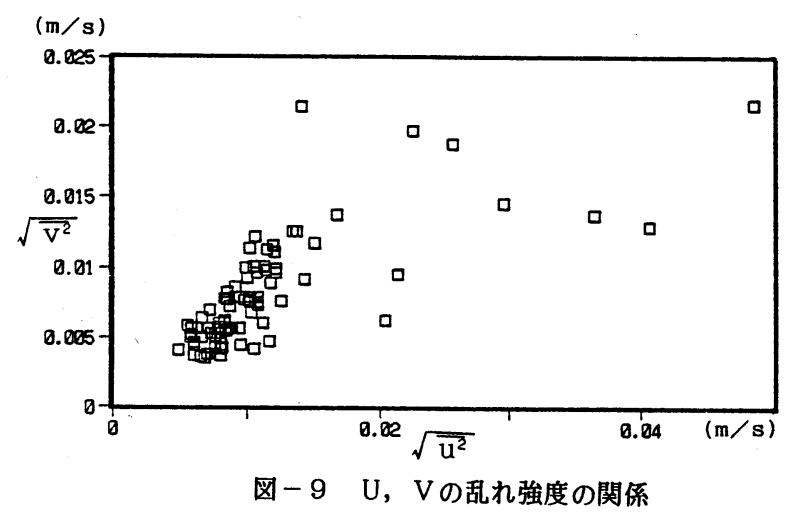
データのばらつきが見られるが、0.0 $2 \mathrm{~m} / \mathrm{s}$ 程度まではほぼ線形の関係にあり、Uの乱れ強度はV $\mathrm{V}$ 約 1 . 3倍を示している。

4.おわりに

今回の解析では、流速勾配やリチャードソン数といつた平均場の量と乱流量とを結び付けるところまでは 解析が進まなかった。今後、さらに多くのデー夕収集と詳細なデー夕解析により実河川の乱流特性を明らか にしていくつもりである。

本研究を進めるにあたり、現地調査およびデータの整理・解析において北海道大学大学院学生 北元正宏君 と八戸工業大学学生 児玉幸雄君の助力を頂いた。また、本研究は文部省科学研究費 (奖励A N0.02855134 ）の補助を受け実施できたことを報告するとともに、感謝の意を表する次第である。

\section{参 考 文 献}

（1）吉田静男・西田修三：天塭川河口密度流における鉛直流速分布、第 31 回水理講演会論文集、1 1987.

（2）西田修三：実河川の乱流計測（2）、土木学会東北支部技術研究発表会、1990.

（3）吉田静男：レーザードップラー流速計によるフィールド水流計測、光学、Vol.16、No.7、1987. 